CARADDE: Jurnal Pengabdian Kepada Masyarakat
$\begin{gathered}\text { https://journal.ilininstitute.com/index.php/caradde } \\ \text { Volume 2 | Nomor 2 | Februari | } 2020 \\ \text { e-ISSN: 2621-7910 dan p-ISSN: 2621-7961 }\end{gathered}$
DOI: https://doi.org/10.31960/caradde.v2i2.345

\title{
Makanan Olahan Berbasis Ikan Patin Di Pondok Pesantren Nurul Hidayah Desa Sungai Salai Kecamatan Candi Laras Utara Kabupaten Tapin Propinsi Kalimantan Selatan
}

\section{Barsihanor, $^{1,}$ Iman Setya Budi ${ }^{2}$}

Keywords:
Makanan
Olahan
Ikan Patin
Corespondensi Author
Pendidikan Guru MI dan Ekonomi
Syariah, Universitas Islam Kalimantan
Muhammad Arsyad Al-Banjari
Banjarmasin
Jl. Adhyaksa, No.02
Email: barsihanor90@gmail.com

\section{History Article}

Received: 11-November-2019; Reviewed: 17-Desember-2019; Accepted: 09-Januari-2019; Avalaible Online: 16-Januari-2019; Published: 04-Februari-2020;

\begin{abstract}
Abstrak. Kegiatan PKM ini bertujuan Memberikan pengetahuan proses produksi, pengelolaan keuangan dan pemasaran. Metode yang digunakan dalam pengabdian ini adalah pelatihan proses produksi, pengelolaan keuangan dan pemasaran. Dalam program kemitraan masyarakat ini, kegiatan-kegiatan PKM yang diakukan antara lain adalah, (1) Persiapan, yakni melakukan kegiatan survey pendahuluan ke lokasi mitra. Pelaksanaan. (2) Pelaksanaan, seperti seminar kewirausahaan, penyampaian materi mengenai pengelolahan kerupuk ikan patin, prosedur pembuatan kerupuk ikan patin dari pertama hingga terakhir, pelatihan pemasaran dan pendampingan, manajemen keuangan.
\end{abstract}

\begin{abstract}
This PKM activity aims to provide knowledge of the production process, financial management and marketing. The method used in this service is training in the production process, financial management and marketing. In this community partnership program, PKM activities that are carried out include, among others, (1) Preparation, namely conducting preliminary survey activities to partner locations. Implementation. (2) Implementation, such as entrepreneurship seminars, delivery of material on the management of catfish crackers, procedures for making catfish crackers from the first to the last, marketing training and assistance, financial management.
\end{abstract}

\section{PENDAHULUAN}

Ikan patin mulai dikenal di Indonesia sekitar tahun 1970-an dan berkembangan sampai saat ini. Indonesia memiliki potensi yang besar dalam budidaya ikan patin, kerena ikan ini mudah dibudidayakan baik dalam kolam maupun karamba. Selain itu, teknologi pembudidayaan ikan patin telah dikuasai mulai dari proses pematangan gonad induk, penetasan telur, pemeliharaan larva, pendederan hingga pembesaran. (Meilisza, 2009)

Provinsi Kalimantan Selatan dijadikan sentra produksi ikan patin nasional. Pemerintah menetapkan wilayah itu sebagai minapolitan ikan patin, yaitu sebagai program pengembangan kawasan ekonomi perikanan yang terintegrasi, yakni, produksi, pengolahan, dan pemasaran. Ketua Umum Klub Ikan Patin Indonesia (CFCI) Midhan Atmaja, mengemukakan, Kalimantan Selatan 
mampu memasok sedikitnya 40 ton ikan patin per hari untuk wilayah Kalimantan. Pihaknya siap memasok 40 ton ikan untuk olahan ke DKI Jakarta. Potensi lahan ikan patin di wilayah itu mencapai 6.000 hektar. (Kompas.com, 2011).

Ikan patin merupakan ikan yang memiliki banyak kelebihan, di antaranya pertumbuhannya yang cepat, kemampuan adaptasi yang mudah, dagingnya yang enak, dan kandunag gizinya yang tinggi. Walau begitu, ikan patin juga memiliki kekurangan, di antranya memiliki kandungan lemak yang tinggi dan $\mathrm{pH}$ tubuh ikannya mendekati netral yang berakibat daging ikan akan mudah membusuk, oleh karena itu diperlukan proses pengolahan untuk pemanfaatannya menjadi berbagai bentuk produk olahan, yaitu konsentrat protein ikan (Isnaini \& Isnaini, 2011).

Kabupaten Banjar merupakan daerah penghasil ikan patin terbesar di Kalimantan. Ikan patin merupakan ikan unggulan di Kabupaten Banjar dengan produksi tahun 2018 sebesar $30.187,75$ ton atau 51,95 persen dari total produksi budidaya tahun 2017 sebesar 58.105 ton. (Kab. Banjar, 2018). Selain Kabupaten Banjar setidaknya ada empat kabupeten lain di Kalimantan Selatan yang memiliki potensi penangkaran ikan air tawar, yaitu Kabupaten Tapin, Hulu Sungai Selatan (HSS), Hulu Sungai Tengah (HST), dan Kabupaten Hulu Sungai Utara (HSU).

Kabupaten Tapin sebagai salah satu daerah di Kalimantan Selatan yang memiliki potensi yang besar di bidang perikanan yang cukup besar, hal tersebut terlihat dari wilayah daerah tersebut yang dilalui oleh Sungai Barito, pembudidayaan ikan dapat dilakukan di wilayah sungai, rawa, kolam dan juga keramba. Salah satunya adalah pembudidayaan Ikan Patin yang dilakukan oleh Pondok Pesantren Nurul Hidayah yang terletak di J1. Tepian kali Negara Desa Sungai Salai Hlir RT. 06, RW. 03 Kecamatan Candi Laras Utara, Kabupaten Tapin.

Pondok Pesantren Nurul Hidayah berdiri pada tahun 2002. Pondok Pesantren Nurul Hidayah mempunyai potensi di bidang ekonomi yaitu Pertanian/Agribisnis/Perkebunan. Hal tersebut dikerenakan Pondok Pesantren tersebut terletak di pinggir Sungai Barito dan juga di daerah persawahan. Jumlah santi di
Pesantren Nurul Hidayah adalah 76, dengan perincian jumlah santri pria berjumlah 51 orang dan santri perempuan berjumlah 25 orang, dengan tenaga pengajar berjumlah 24 orang.

Pada saat ini pondok pesantren Nurul Hidayah memiliki beberapa Tambak Ikan Patin yang dimaksudkan agar Pondok Pesantren memiliki usaha sendiri untuk perkembangan Pondok Pesantren. Pondok pesantren tidak boleh lagi dalam perkembanganya bergantung kepada bantuan pemerintah atau pembayaran dari para santri nya, akan tetapi pondok pesantren harus mempunyai usaha yang dapat dijadikan sebagai sumber pendapatan pondok pesantren, seperti yang dilakukan di Pondok Pesantren Ar-Riyadh, mereka mengembangkan usaha perkebunan karet dan usaha koperasi pesantren walaupun masih dalam skala kecil. Hal tersebut diharapkan dapat memberikan tambahan income pesantren dan usaha koperasi ditujukan untuk memenuhi kebutuhan santri sehari-hari. (Ulfah \& , 2015) Menurut Halim dalam (Azizah, 2016) ekonomi bagi pondok pesantren merupakan jantung kehidupan bagi kemajuan dan perkembangan peradaban.

Hasil panen kolam ikan patin Pondok Pesantren Nurul Hidayah di desa Sungai Salai, 100\% mereka jual kepada tengkulak yang datang ke desa tersebut. Tidak pernah mereka jual sendiri ke pasar ataupun di olah menjadi makanan lain.

Ada beberapa permasalahan yang dialami oleh Pondok Pesantren Nurul Hidayah di antaranya adalah penurunan harga jual ikan patin, hal tersebut meyebabkan pendapatan pondok pesantren dari penjualan ikan patin mengalami penurunan, seperti pengeluaran tak sesuai dengan pemasukkan, belum lagi ketika ada kenaikan harga pakan. Disamping murahnya harga penjualan Ikan Patin, ketidak seimbangan antara capaian hasil panen ikan patin dengan yang membeli ikannya. Hal itu kerena banyaknya hasil panen pembudidaya ikan yang juga kesulitan dalam hal pemasaran. Menurut Moh As'ad strategi pemasaran yang dapat dilakukan untuk mendapatkan pasar harus memperhatikan keinginan dan kebutuhan konsumen di pasar, disamping itu penyajian dengan cara-cara yang khas juga perlu diperhatikan, dan 
efesiensi serta membuat jaring-jaring saluran yang efektif dari produsen ke konsumen dengan mempertimbangkan faktor laba (profit) yang rasional. (Alifuddin, 2013)

Sulitnya menjual atau memasarkan hasil panen ikan patin membuat pondok pesantren lebih memilih untuk tidak melakukan panen dan membiarkan tambak ikan patin tersebut, hal tersebut tentu saja membuat pendapatan pondok pesantren menjadi menurun dari hasil usaha tambak ikan patin tersebut. Maka dari itu perlu adanya terobosan baru yang harus dilakukan pihak pondok pesantren agar pendapatan mereka dari ikan patin tetap tinggi. Ikan patin sebagai salah satu ikan air tawar memiliki produk olahan yang beragam. Produk olahan yang ada merupakan pemanfaatan dari daging, tulang atau duri, dan kulit ikan, (Andriani, 2014) salah satunya dengan membuat berbagai produk olahan dari ikan patin sebagaimana yang telah dilakukan di daerah lain seperti bakso dan nugget patin, hal tersebut akan memberikan alternatif baru bagi konsumen untuk menikmati ikan patin dengan praktis dan lezat. (Oktavianawati \& Palupi, 2017).

Hal yang sama juga bisa diadopsi oleh Pondok Pesantren Nurul Hidayah dengan mengolah ikan patin menjadi kerupuk, kerena kerupuk merupakan makanan ringan yang biasanya di gemari oleh orang Indonesia, tak terkecuali di Desa sungai Salai. Kerupuk juga merupakan makanan yang bisa dinkmati oleh semua kalangan, mulai dari anak kecil hingga orang dewas. Untuk mengolah kerupuk yang berbahan ikan patin tersebut tentunya mitra memerlukan bantuan dan bimbingan serta pendampingan dari tim pengusul dalam pembuatan kerupuk dari ikan patin, selain pendampingan produksi kerupuk, pendampingan dalam hal manajemen usha juga sangat perlu dilakukan, guna keberlanjutan dan kemajuan produksi kerupuk ikan patin tersebut. Ada beberapa alat yang diperlukan dalam pembuatan krupuk tersebut, seperti mesin giling daging, mesin pemotong krupuk, mesin peniris minyak, dan mesin press plastik.

\section{METODE}

Dalam rangka mencapai tujuan kegiatan, maka ditempuh langkah-langkah sebagai berikut:
1. Persiapan

2. Pelaksanaan

a. Training kewirausahaan

b. Pelatihan pengelolahan kerupuk

c. Pembuatan kerupuk ikan patin

d. Pelatihan pemasaran dan pendampingan

e. Permodalan dan manajemen keuangan

3. Rancangan Evaluasi

Evaluasi untuk program pelatihan pentingnya kewirausahaan bagi para santri perlu dilakukan untuk mengetahui mengenai tingkat ketercapaian tujuan kegiatan pentingnya kewirausahaan bagi para santri. Rencana evaluasi pelaksanaan kegiatan ini antara lain adalah: (1) Mengadakan pengamatan langsung di lapangan terhadap kondisi usaha mitra; (2) Memonitor perkembangan usaha yaitu kendala yang dihadapi, prestasi yang dicapai terkait dengan omset, aset, kondisi keuangan dan jangkauan pasar.

\section{HASIL DAN PEMBAHASAN}

Melakukan kegiatan survey pendahuluan ke lokasi mitra. Hal itu dilakukan guna mengetahui kesediaan mitra dengan tim pengusul dan sekaligus mengetahui permasalahan mitra setelah itu mencari dan menetapkan solusi bersama yang akan dilakukan. Disamping itu survei juga dilakukan untuk menentukan waktu pelaksanaan dan menentukan kriteria santri yang akan dijadikan peserta program ini.

\section{Seminar kewirausahaan}

Kegiatan seminar kewirausahaan dilaksanakan pada tanggal 26 Juni 2019. Materi yang disampaikan antara lain adalah pentingnya berwirausaha, faktor-faktor penunjang keberhasilan kewirausahaan dan kendala yang biasa dihadapi dalam berwirausaha. 
Caradde: Jurnal Pengabdian Kepada Masyarakat

Vol 2 No 2, Februari 2020

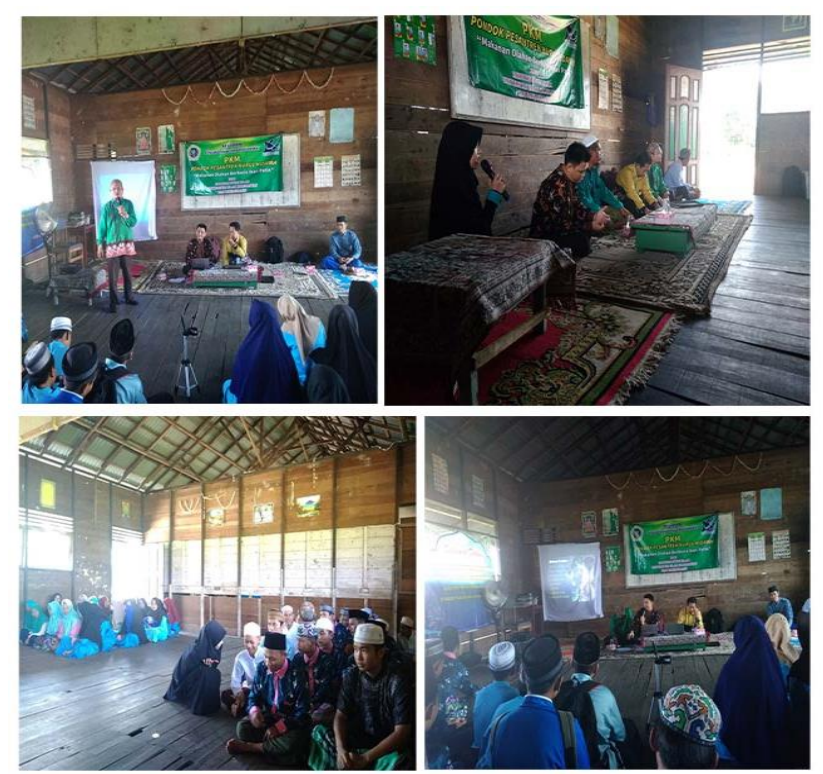

Gambar. 1 .Pelaksanaan Seminar

\section{Pelatihan dan Praktek Pengolahan Produk Pangan dari Ikan Patin}

Pelaksanaan kegiatan yang telah dilakukan antara lain adalah :

Pengolahan Kerupuk Ikan Patin di Pondok Pesantren Nurul Hidayah dilakukan pada tanggal 29 Juni 2019 yang diikuti oleh pengasuh pondok dan 20 orang satri yang terdiri dari 7 orang peserta laki-laki dan 13 orang peserta perempuan. Peserta kegiatan adalah santri Pondok Pesantren Nurul Hidayah yang sudah duduk di bangku sekolah menengah atas adalah :

Agenda dalam kegiatan ini antara lain

a. Pembukaan,

b. Pengenalan bahan utama dan bahan penunjang untuk mengolah produk krupuk ikan patin,

c. Pengetahuan tentang komposisi bahan utama dan penunjang yang terdiri dari:
1) Ikan Patin
$=200$ gram
2) Tepung Tapioka
$=400$ gram
3) Lada
$=1 / 2 \mathrm{sdt}$
4) Ketumbar
$=1 / 2 \mathrm{sdt}$
5) Kaldu buuk
$=1 / 2 \mathrm{sdm}$
6) Bawang Putih $=5$ siung

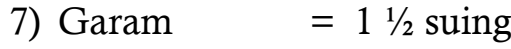
8) Gula = $1 \mathrm{sdm}$

Pelaksanaan kegiatan pengolahan krupuk ikan patin terdiri dari tahapan persiapan bahan utama dan bahan penunjang seperti mengambil daging ikan, menimbang, penyiapan bumbu, pencampuran, pengadukan, pengukusan, pencetakan, pemotongan, penjemuran hingga penggorengan.

Gambar pelaksanaan kegiatan di Pondok Pesantren Nurul Hidayah dapat dilihat pada gambar-gambar berikut ini:

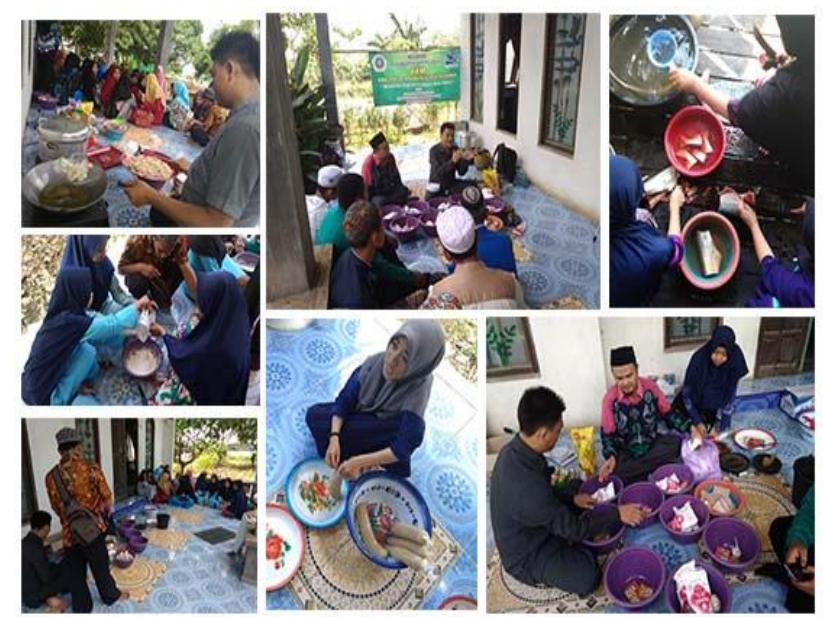

Gambar. 2. Pengolahan Krupuk

\section{Pelatihan Pengemasan}

Kegiatan ini dilaksanakan pada tanggal 03 Juli 2019 di Pondok Pesantren Nurul Hidayah berupa kegiatan pelatihan kemasan dan pembuatan stiker pemasaran serta penggunaan mesin seller untuk meningkatkan daya simpan produk krupuk ikan patin

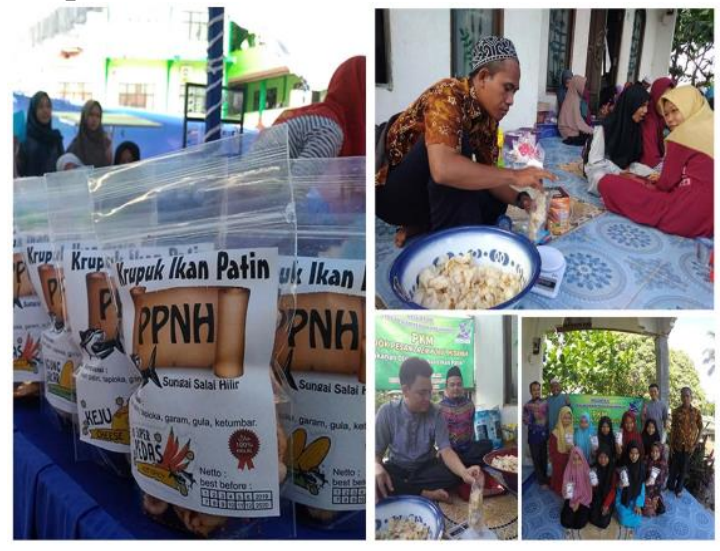

Gambar. 3 Pengemasan

\section{Pendampingan Pemasaran}

Kegiatan pendampingan pemasaran yang telah dilakukan dalam rangka membantu proses pemasaran produk-produk hasil kegiatan antara lain adalah mendisain 
stiker kemasan produk dan memasarkan produk krupuk ikan patin melalui event pekan ilmiah pada tanggal 29 - 31 Juli 2019 melalui stand Fakultas Studi Islam UNISKA dan kegiatan event festival Ekonomi Syariah Kawasan Timur Indonesia FESyar KTI di Hall Atrium Duta Mall Banjarmasin pada tanggal 12 - 14 September 2019

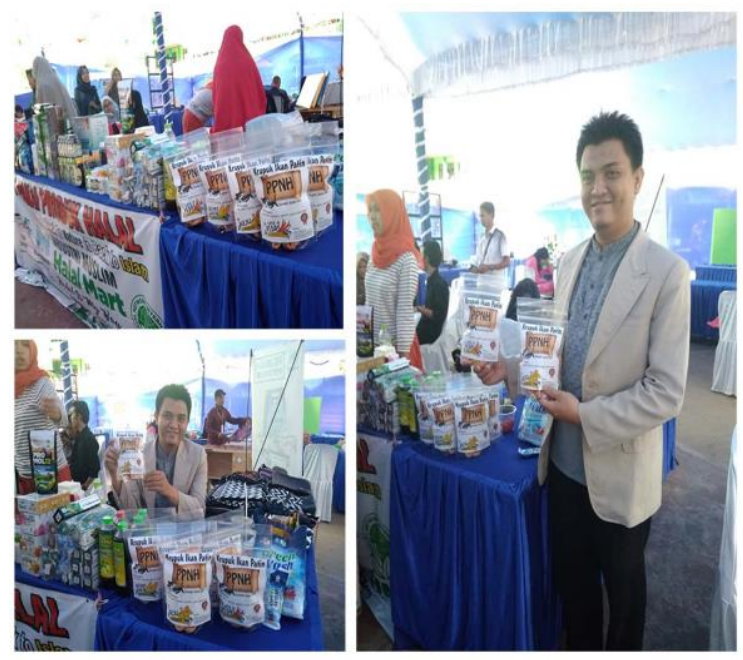

Gambar. 4. Pendampingan Pemasaran

\section{Pelatihan Manajemen Keuangan dan Permodalan}

Kegiatan ini dilaksanakan pada tanggal 21 Oktober 2019 yang berisikan penjelasan mengenai cara menentukan harga pokok produksi, penentuan harga jual, perhitungan keuntungan usaha dan seputar permodalan.

Gambaran perhitungan harga pokok produksi dan perhitungan keuntungan usaha krupuk ikan patin adalah sebagai berikut:

Tabel 1. Analisis Harga Pokok Produksi Krupuk Ikan Patin per Kg Bahan Baku

\begin{tabular}{llc}
\hline No & \multicolumn{1}{c}{ Uraian } & $\begin{array}{c}\text { Produk } \\
\text { Krupuk } \\
\text { Ikan Patin } \\
\text { (Rp) }\end{array}$ \\
\hline 1 & Output & $\begin{array}{c}10 \\
\text { Bks } / 200 \text { gr }\end{array}$ \\
\hline 2 & Harga Jual/bks & 10,000 \\
\hline 3 & Total Penjualan (A) & 100,000 \\
\hline 4 & $\begin{array}{l}\text { Biaya Tetap (B) } \\
\text { (sewa peralatan \& } \\
\text { tempat) }\end{array}$ & 15,000 \\
\hline
\end{tabular}

\begin{tabular}{|c|c|c|}
\hline 5 & $\begin{array}{lr}\begin{array}{l}\text { Biaya } \\
\text { (Bahan }\end{array} & \text { Variabel } \\
\text { Tenaga } & \text { Kerja, } \\
\text { Listrik \& } & \text { Gas } \\
\text { Kemasan, } & \\
\text { Pemasaran) } & \text { (C) }\end{array}$ & 52,500 \\
\hline 6 & $\begin{array}{l}\text { Total Biaya }(\mathrm{D}=\mathrm{B} \\
+\mathrm{C})\end{array}$ & 67,500 \\
\hline 7 & $\begin{array}{l}\text { Keuntungan (A - } \\
\text { D) }\end{array}$ & 32,500 \\
\hline 8 & Gross Profit Margin & $33 \%$ \\
\hline 9 & $\begin{array}{l}\text { BEP Produksi } \\
\text { (Bungkus) }\end{array}$ & $\begin{array}{c}3 \text { Bks } \\
\text { (600 } \\
\text { Gram) }\end{array}$ \\
\hline 10 & $\begin{array}{l}\text { BEP Penjualan } \\
(\mathrm{Rp})\end{array}$ & 60,000 \\
\hline
\end{tabular}

Berdasarkan gambaran harga pokok produksi dan perhitungan keuntungan, maka usaha pengolahan krupuk ikan patin dinilai cukup menguntungkan dengan tingkat keuntungan diatas $30 \%$ sehingga dinilai memiliki prospek dan potensi untuk dikembangkan oleh mitra PKM untuk mendukung keuangan operasional pondok.

\section{SIMPULAN DAN SARAN}

Beberapa hal yang dapat disimpulkan atas pelaksanaan kegiatan adalah (1) Potensi dan prospek usaha pengolahan krupuk ikan patin cukup baik untuk dikembangkan karena bahan baku yang cukup tersedia di Tapin, memiliki tingkat keuntungan usaha yang cukup baik serta peluang pemasaran masih terbuka lebar; (2) Mitra PKM telah dibekali dengan pengetahuan, ketrampilan dan sarana produksi yang cukup untuk memulai usaha di bidang pengolahan krupuk ikan patin; (3) Tim PKM akan tetap memberikan pendampingan pemasaran dan pengurusan perijinan yang diperlukan untuk menjalankan usaha pengolahan krupuk ikan patin; (4) Para peserta kegiatan cukup antusias dan tertarik untuk mengembangkan usaha di bidang pengolahan krupuk ikan patin; (5) Masih adanya kendala berupa proses penjemuran yang masih mengandalkan panas matahari sehingga proses produksi masih sangat tergantung pada cuaca.

Berdasarkan hasil kegiatan, maka saran yang dapat diberikan untuk kegiatan PKM selanjutnya adalah perlu kiranya membuatkan oven ruangan sederhana untuk 
proses penjemuran krupuk ikan patin serta memasukkan kegiatan renovasi dapur pondok yang akan dijadikan sebagai tempat pengolahan agar proses pengolahan tetap dapat dilaksanakan secara higienis.

\section{Daftar Rujukan}

Alifuddin, M., 2013. Penguatan Kemandirian Santri Anak Jalanan Melalui Usaha. Al-Izzah, Volume 8, p. 196.

Andriani, T., 2014. Pelatihan Pengolahan Ikan Patin Menjadi Makanan Variatif dan Produktif di Desa Sawar Kecamatan Kampar Utara Kabupaten Kampar. Kewirausahaan, Volume 13, p. 86

Azizah, S. N., 2016. Manajemen Unit Usaha Pesantren Berbasis Ekoproteksi. AlTijary, Volume 2, p. 78.

D. \& Isnaini, S., 2011. Pemanfaatan Konsentrat Protein Ikan Patin. Pengolahan Hasil Perikanan Indonesia, pp. Vol. XIV, No. 1 (3034).

Kab. Banjar, M. C., 2018. Unit Pengolahan Ikan Mulai Beroperasi. [Online] Available at: http://mc.banjarkab.go.id/2018/0 3/unit-pengolahan-ikan-mulaiberoperasi.html Kompas.com, 2011. Kalimantan Selatan Jadi Minapolitan Patin. [Online] Available at:ttps://nasional.kompas.com/rea d/2011/09/15/15012932/kaliman tan.selatan.jadi.minapolitan.patin
Meilisza, N., 2009. Budidaya Ikan Patin di Vietnam: Suatu Kajian untuk Pengembangan Budidaya Ikan Patin Indonesia. Media Akuakultur, pp. Vol. 4, No. 1 (26).

Oktavianawati, I. \& Palupi, N. W., 2017. Pengolahan Ikan Patin Menjadi Produk Makanan Patin Presto, Bakso Dan Nugget di SemboroJember. $A B D I$, Volume 2, p. 42.

Sulistyo, 2010. Pengembangan Usaha Kecil Dan Menengah Dengan Basis Ekonomi. Jurnal Ekonomi Modernisasi, pp. 6 (1) : 58 - 73.

Sulistyowati, E. E. \& S, H. U., 2016. Pengaruh Pendidikan Kewirausahaan Di Lingkungan. Jurnal Pendidikan: Teori, Penelitian dan Pengembangan, pp. 1 (11) : 2226 - 2229.

Ulfah, N. \& M., 2015. Minat Wirausaha Kaum Santri dan Faktor-faktor yang Mempengaruhinya (Studi pada Pondok Pesantren Ar-Riyadh Palembang). I-Economics, Volume 1, p. 2. 